\title{
Manufacture and Use of Semi-Finished Fig Products in Biscuit Production
}

\author{
N.G. Hovhannisyan, A.S. Aloyan, A.M. Durgaryan \\ Armenian National Agrarian University \\ narinehovhannisyan1984@mail.ru, aloyan.anna94@mail.ru, durgaryan98.an@mail.ru
}

\section{A RT I CLE INFO}

Keywords:

fig,

filler,

confectionery,

biscuits,

syrup of stevia,

functional food

\begin{abstract}
A B S T R A C T
The use of natural ingredients is one of the ways to handle the problems related to the development of new technology for specialized domestic bakery production, whereas in case of their deficit the complete use of food nutrients becomes rather difficult.
\end{abstract}

So, we have set up a goal to develop a technology for functional biscuit production by using semi-finished fig products and at the same time replacing sugar with sugar substitutes of natural origin and low cost price.

Since the production of such food varieties is rather restricted in our country, the new product obtained through the recommended technology would provide an additional opportunity to develop the sector of dietary food production.

\section{Introduction}

Confectionery production technologies in food enterprises, as well as in many other confectionery production sectors have undergone significant changes in recent years. In contemporary conditions, confectionery production units produce a wide range of food products that are significantly different in their composition, production technologies and consumer properties. Despite the fact that they are not staple products, they are in high demand among the population due to their consumer attractiveness (especially for children) (Aksenova, 2005, Toshev and Chaika, 2004).

In the current production stage, it is relevant to identify such development trends for confectionery production, which are aimed at the introduction of innovation technologies and stem from the following premises: world trends in life patterns, identification of demands among the consumer target groups, expectations of consumer attractiveness for the product and competition increase in globalization conditions.

Flour products have a considerable share (about $50 \%$ ) in the confectionery market and are in permanent demand among all social strata with different incomes.

Currently the world's leading food trends include organic foods, functional food products, healthy and consistent diet.

Thus, new technologies can be developed with scientific production bases and upon the reference to the traditional technologies (Shenderov, 2003). 


\section{Materials and methods}

The biscuit produced from high quality wheat flour has been used as a control sample, while fresh and dried fig fruits and the stevia syrup have been used as functional components.

Water constitutes about $79.1 \%$ of fig fruit. Carbohydrate is the main macronutrient in the content of this fruit - $19.2 \mathrm{~g}$ per $100 \mathrm{~g}$ fruit; cellulose makes $3 \mathrm{~g}$ of carbohydrates and the remaining $16 \mathrm{~g}$ are sugars.

Fig contains only $0.7 \%$ proteins, while fats are almost missing, which means that it contains very small amount of saturated fats and is absolutely free from cholesterol.

In the mentioned amount of proteins, the essential amino acids like, tryptophan, threonine, valine and histidine make up $2 \%$ each. The content of other irreplaceable amino acids (leucine, lysine, methionine and phenylalanine) are also in equal amounts making $1 \%$ of protein each. Calorific capacity in 100 grams makes $74 \mathrm{kcal}$ (Arendt and Rzhevkin, 1950).

Stevia leaves have been used as a sweetening material in South America and Japan since 1970. It does not have any glycemic index and calories, and its use, as a sweetener, is already common in many countries.

Long-term scientific research on the stevia properties has shown that this plant can be used for a long time, even during the entire lifetime with no adverse effects on human health. In case of its systematic use in the food ration the amount of glucose in the blood of diabetics significantly decreases and the elasticity of vessel walls improve (https:// stevia-steviosidejj-indeks-st-stevii/).

The aim of the current research is to manufacture new functional biscuit products, which will be fit for the target groups including people suffering from diabetes and those following consistent food ration. To this end the following objectives have been developed and implemented:

1. producing functional filler from fresh and dried fig fruits, which can be used in the biscuit production,

2. reducing sugar content in the food product as much as possible replacing it with sugar substitutes,

3. investigating the qualitative properties of the manufactured product, particularly the organoleptic and physicochemical indicators,

4. determining optimal doses of additional raw materials,

5. developing biscuit production technology.

The research methods regulated upon the GOST standards have been used during the investigations in line with the current technical conditions of GOST 24901-2014 (GOST 24901-2014 interstate standard). The biscuit recipe has been drawn up through multicomponent estimation methods.

The experimental sample was baked in 2 ways but with the same technological scheme of production. In the first version, the stevia syrup was added to the fresh fig fruits to prepare pulp filler, and in the second version, it was prepared by adding the syrup of stevia to the dried fig fruits.

\section{Results and discussions}

The trials have been conducted based on the research results related to the control variant of the biscuit product made from the sweet yeast dough and those related to experimental food varieties. The sweet dough biscuit made from the high quality wheat flour has served as a research object, since it contains considerable amount of sugar. Technological description is introduced in Figure 1.

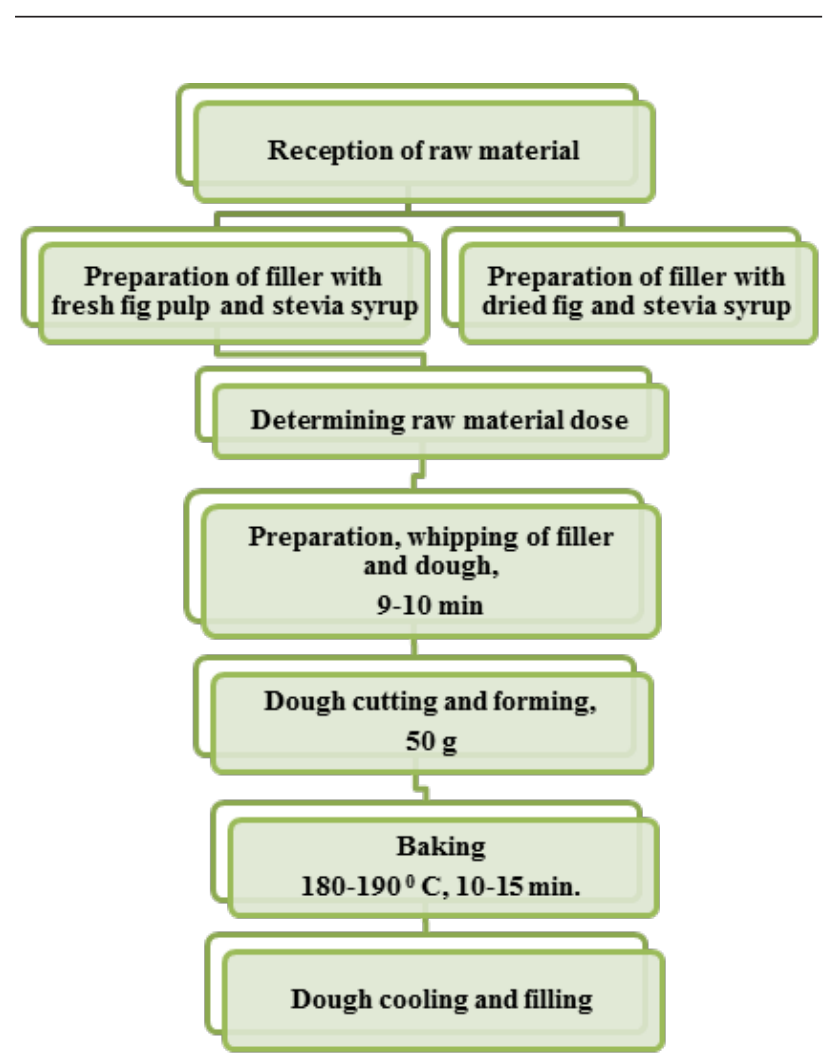

Figure 1. Technological scheme of biscuits (composed by the authors) 
For the study, the stevia syrup was applied, which, unlike the stevioside, has a very delicate and well distinguished sweet flavor. The impact of different doses of stevia syrup added to the fig filler prepared for butter biscuits has been studied. Since fig is seasonal fruit, its filler was prepared with fresh and sugar-free dried fruits.

The finished product was evaluated 4 hours after baking according to its organoleptic and physicochemical properties.

Since one of the research objectives was to avoid using sugar as an ingredient in the butter biscuit, it was replaced with the stevia syrup, glycemic index of which is 0 . The sweetness of the finished product was ensured via the functional filler.

In the first version, the filler mass was prepared from fresh fig by adding 6-7 drips of stevia syrup to $100 \mathrm{~g}$ fig pulp and in the second version 7-8 drips of syrup was added to 100 g sugar-free dried fig fruit.

During the investigations, first of all the effect of the filler on the humidity rate of finished product was examined. The results are presented in Figure 2.

According to Figure 2, the humidity index increased from $15.8 \%$ to $16.6 \%$ and $16.1 \%$, respectively. The increased humidity is due to biscuit fillers, since the semi-finished fig products are endowed with high humidity rate, and hence, affected the humidity index of the finished product as well. This will reduce the shelf life of the finished product to some extent; nevertheless, if we take into account that the food is of functional significance, then that deviation is not so much significant. In case of observing the established technological regulations, the developed technology enables to produce functional food product with efficient organoleptic and physicochemical properties characteristic to finished product (Table 1).

Table 1. Qualitative indicators of finished products*

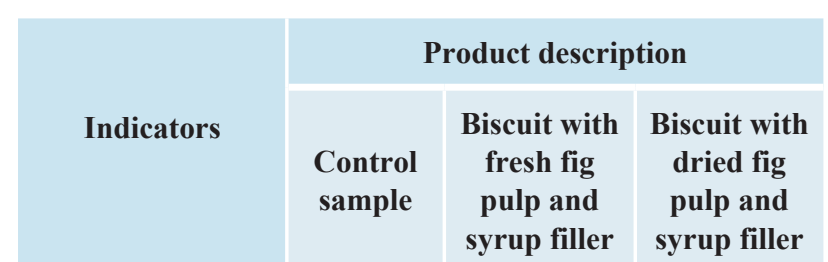

Dough physicochemical indicators

\begin{tabular}{|l|c|c|c|}
\hline $\begin{array}{l}\text { Total sugar } \\
\text { content, \% }\end{array}$ & 45 & 2.1 & 2.4 \\
\hline $\begin{array}{l}\text { Water permeability, } \\
\%, \text { no less than }\end{array}$ & 150 & 153 & 148 \\
$\begin{array}{l}\text { Alkalinity, } \\
\text { no more than }\end{array}$ & 2.0 & 1.8 & 1.9 \\
\hline
\end{tabular}

Physicochemical indicators of the filler

Filler mass content,

$\%$, no less than

Sugar mass content

in the filler,

15

15.3

15.5

$\%$, no less than

65

5.8

5.1

*Composed by the authors.

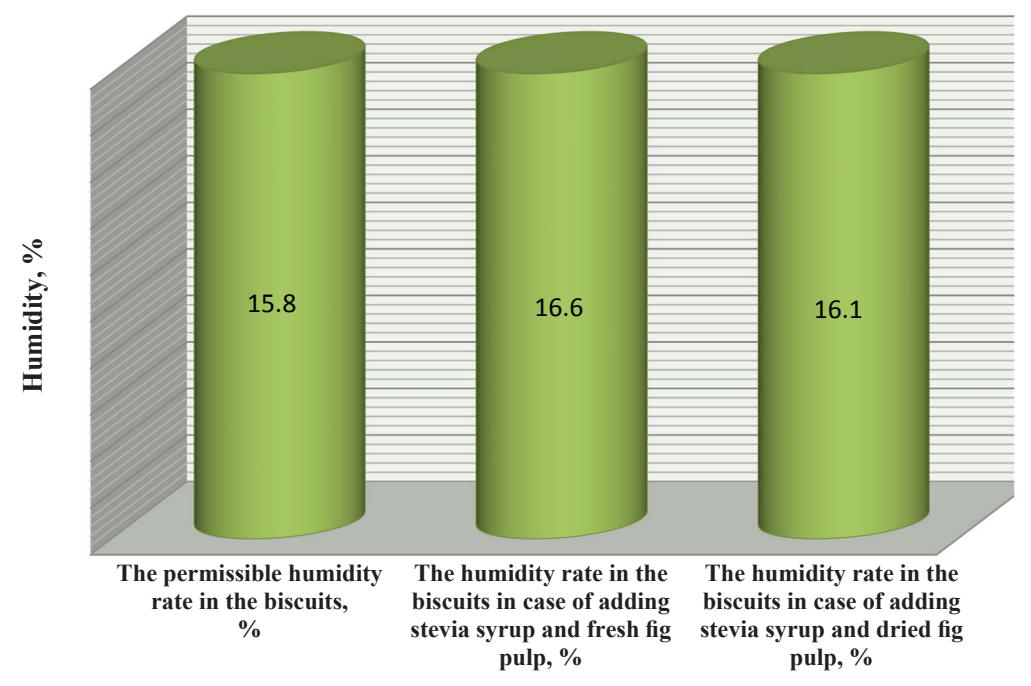

Figure 2. Determining Biscuit Humidity Rate, \% (composed by the authors). 
Since the new food product is intended first for the use of diabetic patients, the most important indicator in such food products is the amount of sugar content.

Table 2. Organoleptic indicators of finished products*

\begin{tabular}{|c|c|c|}
\hline \multirow[b]{2}{*}{ Indicators } & \multicolumn{2}{|c|}{ Product description } \\
\hline & $\begin{array}{c}\text { Control samples of } \\
\text { biscuit }\end{array}$ & $\begin{array}{c}\text { Experimental } \\
\text { samples of biscuit }\end{array}$ \\
\hline $\begin{array}{l}\text { Appearance } \\
\text { Form } \\
\text { Surface }\end{array}$ & $\begin{array}{l}\text { Diverse, without } \\
\text { pores, swellings or } \\
\text { damaged edges }\end{array}$ & $\begin{array}{l}\text { Without pores, } \\
\text { swellings or } \\
\text { damaged edges }\end{array}$ \\
\hline Color & $\begin{array}{l}\text { From light yellowish } \\
\text { to dark brown, } \\
\text { considering the raw } \\
\text { material used }\end{array}$ & Light yellowish \\
\hline Filler mode & Uniformly baked & Baked, non-sticky \\
\hline Taste & $\begin{array}{l}\text { Distinguished, } \\
\text { typical to the taste of } \\
\text { components included } \\
\text { in the biscuit recipe, } \\
\text { without off-taste }\end{array}$ & $\begin{array}{c}\text { Well distinguished, } \\
\text { delicate fig and } \\
\text { stevia taste }\end{array}$ \\
\hline Flavor & $\begin{array}{l}\text { Distinguished, } \\
\text { typical to the flavor } \\
\text { of components } \\
\text { included in the } \\
\text { biscuit recipe, } \\
\text { without off-flavor }\end{array}$ & $\begin{array}{l}\text { Well distinguished, } \\
\text { with delicate fig } \\
\text { flavor and without } \\
\text { off-flavors }\end{array}$ \\
\hline
\end{tabular}

Table 3. The recipe of the biscuit baked with stevia syrup*

\begin{tabular}{|l|c|}
\hline \multicolumn{1}{|c|}{ Raw materials } & Raw material consumption, $\mathbf{g}$ \\
\hline Wheat flour & 250.0 \\
\hline Edible salt & 2.0 \\
\hline Butter & 400.0 \\
Stevia syrup & 1.0 \\
\hline Sunflower oil & 60.0 \\
\hline Dried/fresh fruits of fig & $200 / 150$ \\
\hline Lemon juice & 50.0 \\
\hline
\end{tabular}

The results of the research presented in Table 1 indicate that the sugar mass content in the dough of experimental variants make $2.1 \%$ and $2.4 \%$ respectively against that of the control variant (45). This is due to the fact that sugar was excluded from the dough preparing recipe altogether and the slight sugar content in the experimented samples is probably due to other products used in the recipe, which contain small sugar amounts. The abrupt decline in the sugar content of the filler is due to the syrup application. Here also some sugar content was observed; anyhow it doesn't have anything to do with glucose, but it is rather related with total sugar content in the fig fruit, since stevia syrup doesn't contain any glucose.

According to the organoleptic evaluation, the biscuit obtained pleasant taste but somewhat brown colorings. The taste and flavor of fresh biscuits became more pronounced (Table 2).

The data provided in Table 2 show that the use of syrup and figs enables to improve the organoleptic properties of the baked biscuit as well enhancing its taste (more distinguished) and flavor (more delicate).

Thus, based on the research, a recipe for the new product has been developed (Table 3).

\section{Conclusion}

Based on the experimental research we have come to the conclusion that fig is a rather useful foodstuff, and as a functional component it can be used in the production of functional confectionery. The two possible ways of fig application have been justified, namely its application in fresh and dry (dried fruit) forms, herewith ensuring the seasonality of the product.

The method and optimal doses of stevia syrup application have been developed and identified. In the result of laboratory trials the organoleptic and physicochemical properties of the finished product have been determined.

It has been proved that the sugar content in the new products manufactured through the developed technology and recipe has been minimized, while the application of sugar as such, has been rejected at all, whereupon the glucose content has been also removed.

\section{References}

1. Aksenova, L.M. (2005). Quality is the Main Property of Confectionery Products // Proceedings of the Fifth International Conference "Confectionery, XXI Century”, Moscow, - pp. 14-18. 
2. Arendt, N., Rzhevkin, A. (1950). Subtropical Fruit Crops (Fig, Persimmon, Pomegranate, Feijoa Trees), - Armstatepub, Yerevan, - pp. 8-21.

3. GOST 24901-2014. Interstate Standard "Cookies. General Technical Conditions".

4. https://stevia-steviosidejj-indeks-st-stevii/ (accessed on 03.02.2021).
5. Shenderov, B.A. (2003). Modern State and Prospects of Developing Concept on "Functional Nutrition" // Food industry, - N 5, - pp. 4-7.

6. Toshev, A.D., Chaika, O.V. (2004). More Emphasis on the Processing of Functional Food Products // Confectionery Production. - N 4, - p. 38. 